\title{
Pyrolysation of Pine Merkusii wood bark wastes to produce crude bio-oil using chrome-clay, crl clay catalyst as an alternative energy
}

\author{
Syaiful Bahri ${ }^{1 *}$, Ramadhoni Febrian ${ }^{1}$, Khairat Khairat $^{1}$, and Muhdarina Muhdarina ${ }^{2}$ \\ ${ }^{1}$ Chemical Reaction Engineering Laboratory, Universitas Riau, Pekanbaru, Indonesia \\ ${ }^{2}$ Physical Chemistry Laboratory, Universitas Riau, Pekanbaru, Indonesia
}

\begin{abstract}
In this research, bio-oil is produced from pine wood bark waste biomass through pyrolysis using $\mathrm{Cr} /$ clay catalyst. This research aims to produce bio-oil from bark of pine with $\mathrm{Cr} /$ clay catalyst as an alternative fuel. The effect of the ratio of catalyst $\mathrm{Cr} /$ clay weight to biomass and influence of Chromium (Cr) impregnation on clay as catalyst were investigated. Then, the characterisation of physical and chemical characteristics of crude bio-oil produced were measured. For each of the pyrolysis runs, $50 \mathrm{~g}$ of pine bark having $-100+200 \mathrm{mesh}$, the $\mathrm{Cr} / \mathrm{clay}$ catalysts having weight variations to biomass of $3 \%, 5 \%$, and $7 \%$, respectively, and then variation of Chromium $(\mathrm{Cr})$ impregnation on clay of $0 \%, 1 \%, 2 \%$, and $3 \%$, respectively, were used. For any experimental run, $500 \mathrm{ml}$ of silinap was added to the pyrolysis reactor as thermal homogenized aid. Pyrolysis process was carried out for 120 minutes at $320^{\circ} \mathrm{C}$ and having stirring speed $300 \mathrm{rpm}$. As a result, the greatest percentage of bio-oil yield of $65.77 \%$ was given of the run having $\mathrm{Cr} /$ clay catalysts $7 \%$ and $3 \%$ of impregnated Chrome content. Characterisation measurement of bio-oil of physical properties was obtained as follows: density $0.812 \mathrm{~g} / \mathrm{ml}$, viscosity $0.902 \mathrm{cSt}$, acidity $7.626 \mathrm{mg} . \mathrm{NaOH} / \mathrm{gram}$, and flash point $31^{\circ} \mathrm{C}$, respectively. In addition, the chemical characteristics of the bio-oil were obtained using Gas Chromatography-Mass Spectroscopy (GCMS): analysis found several chemical components as follows, such 9,12-Octadecadienoyl chloride, Cyclohexane, 1-methyl-2-penthyl, Octadecanoic acid, 2-Pentene, 24.4-trimethyl, and Cyclohexane, 3- (3,3dimethylbutyl).
\end{abstract}

\section{Introduction}

Indonesia possesses various types of energy sources in considerable amounts. However, until now, in general, it still relies on energy derived from fossil fuels. The energy consumption in Indonesia is fuel oil, which is derived from petroleum. Indonesia's dependence on fossil fuels is almost 97\% [1]. Having a limited amount and huge usage, it can be predicted that oil reserves will shortly be depleted.

*Corresponding author: syaifulbahri@eng.unri.ac.id 
Therefore, we need alternative energy sources which are renewable and can replace fossil fuels. Alternative energy sources that are currently being developed include biomassbased energy sources such as bio-oil. One of the potential biomasses to be developed into raw material for making bio-oil is pine bark. Pine bark has only previously been regarded as plantation waste or industrial waste. The paper pulp processing industry only uses pine wood while the waste is used as fuel for boilers. In addition to the amount being relatively abundant, pine bark also contains a high degree of holoselulose and lignin, of $59.38 \%$ and $40.43 \%$, respectively [2]. Both of these components are the primary raw materials of biooil.

In order to produce the bio-oil, a catalyst is used to accelerate the reaction. Natural clay can be used as a catalyst due to its large pore size of up to $98 \mathrm{~m}^{2} / \mathrm{g}$, high thermal stability up to $600^{\circ} \mathrm{C}$ and good catalytic activity [3]. Clay is abundant in huge amounts in Riau Province, such as in Kuantan Singingi which has clay reserves amounting to 4.3137 million $\mathrm{m}^{3}[4]$.

Metal catalysts are used to produce a better performance. The metal used is a transition metal of groups such as $\mathrm{Cr}, \mathrm{Ni}, \mathrm{Mo}$, and $\mathrm{Co}$. However, $\mathrm{Cr}$ has been selected for this purpose as $\mathrm{Cr}$ is more reactive than the other metals in forming bonds with the reactants.

The process used to produce bio-oil is called pyrolysis. Compared with other biomass processing technology, pyrolysis is better to produce liquid products. Compared with gasification and combustion, which produces only $5 \%$ and $30 \%$. of the liquid product, respectively, pyrolysis can generate up to $75 \%$ liquid [5]. Therefore, this study is focused on producing bio-oil using pine bark merkussi as a raw material and $\mathrm{Cr} /$ clay as a catalyst, studying the effect of catalyst weight ratio of $\mathrm{Cr} / \mathrm{clay}$, the impact of the ratio of biomass to bio-oil yield and determining the physical and chemical characteristics of bio-oil.

\section{Research methods}

\subsection{Materials}

Raw materials included were pine bark, clay, $\mathrm{H}_{2} \mathrm{SO}_{4} 1.2 \mathrm{M}$ (Merck), $\mathrm{BaCl}_{2}$ (Merck), distilled water (Brata Chem), $\mathrm{N}_{2}, \mathrm{O}_{2}$, and $\mathrm{H}_{2}$ (Aneka Gas), $\mathrm{CrCl}_{3} \cdot 6 \mathrm{H}_{2} \mathrm{O}$ (Merck), $0.1 \mathrm{~N}$ $\mathrm{NaOH}$ (Merck), Oxalic acid 0.2 N (Merck), indicators Phenolphthalein and silinap $280 \mathrm{~m}$ (Pertamina).

\subsection{Equipments}

Tools used in this study include mortar porcelain, 100 and 200 mesh sieves, reactor flatbed size of 1 liter and a pyrolysis reactor connected to a condenser. Different measuring equipment, such as Gas Chromatography-Mass Spectroscopy (Shimadzu type 2010S) and Brenet Emmet Teller (Nova 3200e Quantachrome) were used.

\subsection{Preparation of $\mathrm{Cr} /$ Clay catalyst}

Firstly, clay lumps were crushed and sieved to $-100+200$ mesh size. Furthermore, to activate the clay, $75 \mathrm{~g}$ were soaked in a solution of $\mathrm{H}_{2} \mathrm{SO}_{4} 500 \mathrm{ml}$ of $1.2 \mathrm{M}$ for six hours at a temperature of $60^{\circ} \mathrm{C}$ while stirring in the reactor. Then, the sample was allowed to stand for 16 hours and then filtered and washed repeatedly using distilled water until there were no sulfate ions left in the solution. The cake was then dried at a temperature of $120^{\circ} \mathrm{C}$ for four hours [6].

Impregnation of $\mathrm{Cr}$ was done in a way that activated the clay sample which was dissolved in $200 \mathrm{ml} \mathrm{CrCl}_{3} \cdot 6 \mathrm{H}_{2} \mathrm{O}$ and stirred with a magnetic stirrer while heated using a hot 
plate at a temperature of $60^{\circ} \mathrm{C}$ for three hours, then dried in an oven for six hours at a temperature of $110^{\circ} \mathrm{C}$ to obtain the $\mathrm{Cr} /$ clay catalyst.

The next stage was the calcination of the catalyst. Samples of $\mathrm{Cr} /$ clay were inserted into the tube and then calcinated for six hours at a temperature of $500^{\circ} \mathrm{C}$ under a nitrogen gas flow of $400 \mathrm{ml} / \mathrm{min}$. The sample was then oxidized at a temperature of $400^{\circ} \mathrm{C}$ using oxygen gas with a flow rate of $400 \mathrm{ml} / \mathrm{min}$ for two hours and a reduction in temperature to $400^{\circ} \mathrm{C}$ using hydrogen gas of $400 \mathrm{ml} / \mathrm{min}$ for two hours [6]. The catalyst results were characterized using BET to determine the surface area of the catalyst.

\subsection{Pyrolysis bio-oil}

Pine bark of pine merkussi and catalyst $\mathrm{Cr} /$ clay with a specific percentage variation of $3 \%$, $5 \%$, and $7 \% \mathrm{w} / \mathrm{w}$ of the biomass were loaded into the pyrolysis reactor. The pyrolysis process was s carried out for 120 minutes at a temperature of $320^{\circ} \mathrm{C}$ in nitrogen gas flow of $1.35 \mathrm{ml} / \mathrm{sec}$ and stirred with a speed of $300 \mathrm{rpm}$. The vapor was allowed to go through the condenser to be condensed into a liquid bio-oil.

\subsection{Characterisation of bio-oil}

The bio-oil obtained is characterized by its physical properties, such as density, viscosity, acidity, and flash point. Chemical analysis of chemical compounds was done using Gas Chromatography-Mass Spectroscopy.

\section{Results and discussion}

\subsection{Effect of variations $\mathrm{Cr}$ on catalysts to bio-oil produced}

In this study, variations of the metal content of chromium, Cr, of $0 \%, 1 \%, 2 \%$, and $3 \% \mathrm{w} / \mathrm{w}$ on clay and catalyst weight variation of $3 \%, 5 \%$, and $7 \% \mathrm{w} / \mathrm{w}$ on biomass were investigated. The results showed there is no significant difference in yield by variation of impregnation of $\mathrm{Cr}$. Table 1 shows the variation in impregnation of $\mathrm{Cr}$ on clay and $7 \%$ catalyst to biomass, as follows.

Table 1. Cr loading, catalyst weight, and yield bio-oil.

\begin{tabular}{|c|c|c|}
\hline Cr loading (\%) & Catalyst to biomass ratio (\%) & yield bio-oil (\%) \\
\hline nil (no Cr) & 7 & 57.4 \\
\hline 1 & 7 & 62.09 \\
\hline 2 & 7 & 63.68 \\
\hline 3 & 77 & 65.77 \\
\hline
\end{tabular}

Table 1 shows the yield of bio-oil on $\mathrm{Cr}$ variation of $0 \%, 1 \%, 2 \%$, and $3 \% \mathrm{Cr} /$ clay having yield of $57.6 \%, 62.09 \%, 63.68 \%$, and $65.77 \%$, respectively. Based on these results, it was indicated that having increasing levels of metal improves the yield of bio-oil. This might be due to acting as an active phase in accelerating reaction due to an increased surface area [7].

The surface area becomes a factor that affects the catalyst activity. The surface areas of the catalyst are shown in Table 2 . 
Table 2. Surface area of $\mathrm{Cr} /$ clay catalysts.

\begin{tabular}{|c|c|}
\hline Catalyst & Catalyst to biomass ratio (\%) \\
\hline Clay activated $\left(\mathrm{H}_{2} \mathrm{SO}_{4}\right)$ & 2.377 \\
\hline $\mathrm{Cr} /$ Clay $1 \%$ & 11.300 \\
\hline $\mathrm{Cr} /$ Clay $\%$ & 11.415 \\
\hline $\mathrm{Cr} /$ Clay 3\% & 16.719 \\
\hline
\end{tabular}

Table 2 shows that the activation process clay had a surface area $2.377 \mathrm{~m}^{2} / \mathrm{g}$ and increased after the metal impregnation following calcination, oxidation, and reduction, as the catalyst $\mathrm{Cr}$ / clay, with the higher loading of $3 \% \mathrm{Cr}$, had a higher the surface area of $16.719 \mathrm{~m}_{2} / \mathrm{g}$. Activation of clays seemed to produce larger active sites, increasing the acidity, and improved thermal stability to enhance the adsorption of the clay itself [8]. Likewise, Cr metal impregnation, calcination, oxidation, and reduction also expanded the surface area of the catalyst. With the increased surface area, it allows the increase of catalytically active sites, thus improving catalyst performance [9].

\subsection{Effect of weight variation of catalyst to bio-oil yield}

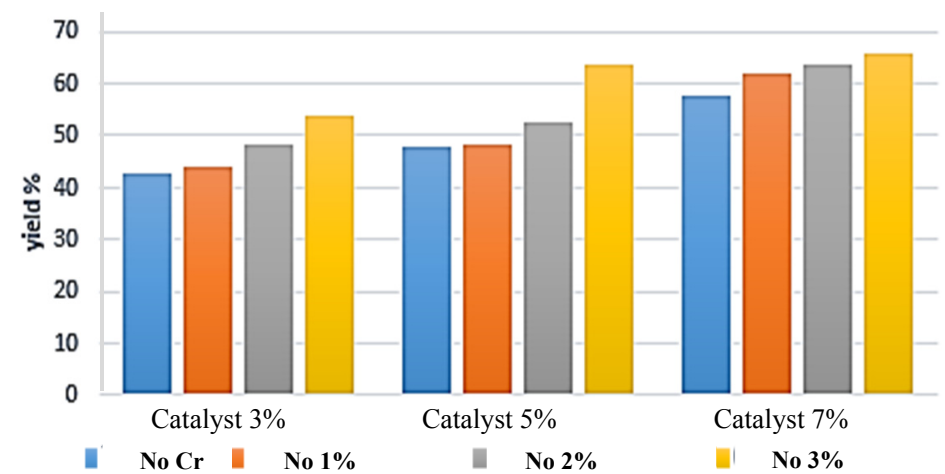

Fig. 1. Various variation of weight of catalyst to bio-oil yield.

Fig. 1 shows that increased weight of catalyst increased bio-oil yield. The highest yield was obtained on catalyst weight $\mathrm{Cr} /$ clay $7 \%$ of $\mathrm{Cr}$ impregnation $3 \%$, having the yield of $65.77 \%$. This $\mathrm{d}$ might be due to a more significant amount of catalyst being used, surface area and the more active. Thus, the possibility of reactants to react with the catalyst will be higher and may increase the bio-oil product.

\subsection{Characteristics of bio-oil}

\subsubsection{Physical properties}

Results of analysis of physical properties of bio-oil can be seen in Table 3 below. Table 3 shows density from $0.792-0.960 \mathrm{~g} / \mathrm{ml}$. Mohan et al. [10] revealed that bio oil density is usually between $0.94-1.2 \mathrm{~g} / \mathrm{ml}$. This low density might cause many compounds of small molecular weight within the bio-oil. 
Table 3. Physical characteristics of bio-oil.

\begin{tabular}{|c|c|c|c|c|c|}
\hline $\begin{array}{c}\mathbf{C r} \\
\text { loading } \\
\%\end{array}$ & $\begin{array}{r}\text { Catalyst } \\
\text { weight \% }\end{array}$ & $\begin{array}{c}\text { Density cSt } \\
\mathrm{g} / \mathrm{ml}\end{array}$ & $\begin{array}{c}\text { Viscosity } \\
\text { cSt }\end{array}$ & $\begin{array}{c}\text { Flash } \\
\text { point }^{\circ} \mathrm{C}\end{array}$ & $\begin{array}{l}\text { Acid number mg } \\
\mathrm{NaOH} / \mathrm{g} \text { sample }\end{array}$ \\
\hline \multirow{3}{*}{0} & 3 & 0.829 & 1.458 & 39 & 12.561 \\
\hline & 5 & 0.884 & 1.144 & 38 & 9.869 \\
\hline & 7 & 0.960 & 1.152 & 40 & 13.907 \\
\hline \multirow{3}{*}{1} & 3 & 0.811 & 0.838 & 34 & 11.215 \\
\hline & 5 & 0.896 & 0.846 & 34 & 5.832 \\
\hline & 7 & 0.887 & 0.951 & 32 & 4.037 \\
\hline \multirow{3}{*}{2} & 3 & 0.821 & 1.273 & 38 & 13.009 \\
\hline & 5 & 0.878 & 1.579 & 33 & 11.215 \\
\hline & 7 & 0.796 & 0.846 & 32 & 8.075 \\
\hline \multirow{3}{*}{3} & 3 & 0.792 & 0.991 & 31 & 8.972 \\
\hline & 5 & 0.793 & 0.878 & 31 & 6.729 \\
\hline & 7 & 0.812 & 0.902 & 31 & 7.6262 \\
\hline
\end{tabular}

Viscosity has a value of $0.838-1.579 \mathrm{cSt}$. This value is sufficiently smaller than the Dynamotive standard [11], which is $1.2 \mathrm{cSt}$. Qi et al. (2007) explained that the low viscosity is due to the high water content in the bio-oil and less content of aromatic compounds.

The flash point is also important to fuel. Dynamotive [2006] states that the flash point of bio-oil is between $31 \%-42^{\circ} \mathrm{C}$, whereas, in this study, it showed a flash point between $31 \%-40^{\circ} \mathrm{C}$. This happens because of the short-chain compounds produced and is the result of decomposition of cellulose and hemicellulose.

The bio-oil products are also acidic because they contain carboxylic acid compounds. Acidity obtained ranged from 4.037-13.009 mg.NaOH/g. Mohan et al. [10] stated bio oil acidity is usually $35.1-50 \mathrm{mg} . \mathrm{NaOH} / \mathrm{g}$ sample. This happens because the bio-oil product contains a small amount of carboxylic acid groups, ranged from 9-13\%.

\subsubsection{Physical properties}

Analysis of components or chemical compound of bio-oil was measured using Gas Chromatography-Mass Spectroscopy (GC/MS), as shown in Fig. 2 below. In the results of analysis given by $1 \% \mathrm{Cr}$ Catalyst and $7 \% \mathrm{w} / \mathrm{w}$ of catalyst to biomass, the dominant compounds contained in the bio-oil were as follows: (A)2-Pentene, 2,4,4-trimethyl (19.98\%), (B)1-propene, 2-methyl, (5.77\%), (C)Cyclohexanone, 3- (3,3-dimethyl butyl) (14.51\%), (D)1-propene, 2-methyl (5.19\%), (E)Silane, Trimethyl-2-Propyne (6.63\%). It was concluded that compounds obtained by pyrolysis depended on the type of biomass, catalysts, and operating conditions. 


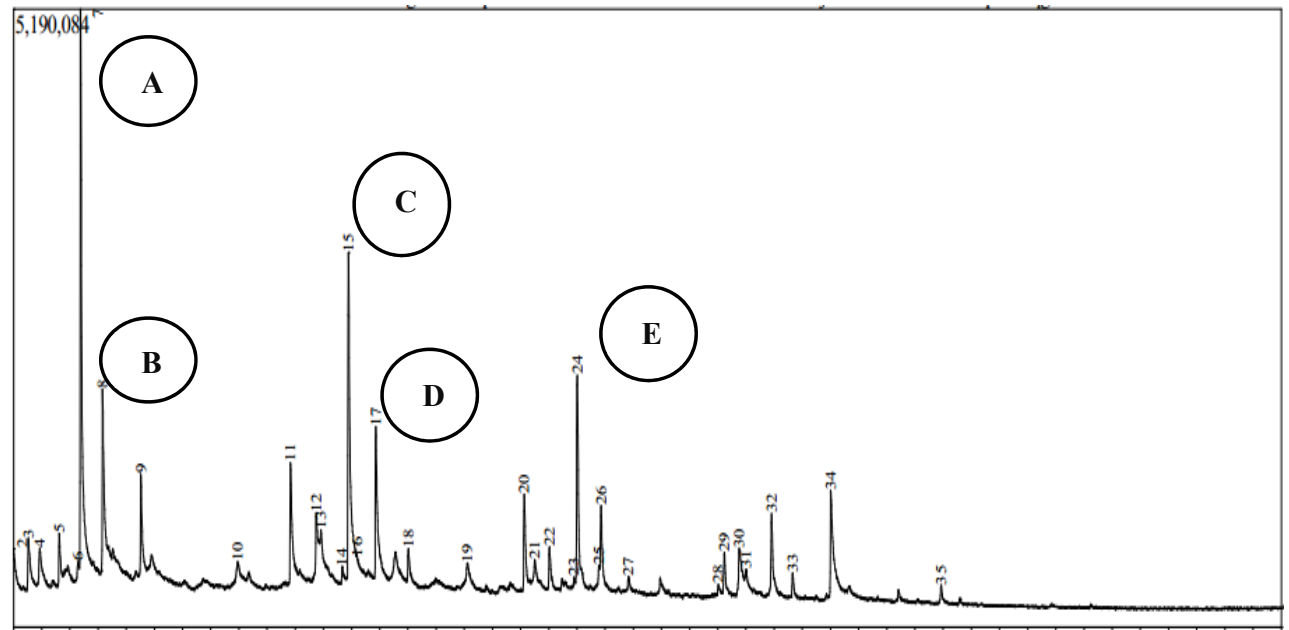

Fig. 2. Chromatogram of bio-oil given by $1 \% \mathrm{Cr}$ catalyst and $7 \% \mathrm{w} / \mathrm{w}$ catalyst to biomass.

\section{Conclusions}

Pyrolysis of pine bark merkusii used catalysts of $\mathrm{Cr} /$ clay to produce bio-oil as an alternative fuel. Increased levels of $\mathrm{Cr}$ on impregnation of catalyst and increased weight of catalyst have proved useful in increased bio-oil. The highest yield was obtained on run of catalysts Cr /clay 7\% by weight of the biomass and metal content of $3 \%$ by as much as $65.77 \%$. Characterization of physical properties of bio-oil at the highest yield shows density $0.812 \mathrm{~g} / \mathrm{ml}$, viscosity $0.902 \mathrm{cSt}$, acidity $7.626 \mathrm{mg} . \mathrm{NaOH} / \mathrm{g}$, and flash point $31^{\circ} \mathrm{C}$, whereas its chemical components are alkenes $83 \%$, alkanes $7.06 \%$, ketone $23.71 \%$, alcohol $8.1 \%$, methyl ester $6.77 \%$, and silanes $11.06 \%$, respectively

\section{References}

1. Kementerian Energi dan Sumber Daya Mineral, Statistik minyak dan gas bumi 2015 (Direktorat Jenderal Minyak dan Gas Bumi, Jakarta, 2016)

2. E. Hassan, P.H. Steele, B. Mitchell, L. Ingram, Physical and chemical characterization of fast pyrolysis bio-oil produced from various southern forestry feedstocks (Forest Products Department, Mississippi State University, 2009)

3. Darwanta, Sriyanto, Science 1 (2008)

4. S. Bahri, R. Rivai, J. of Sci. and Tech. 9, 2 (2010)

5. Innovative Natural Resource Solutions LLC, New Hampshire bio-oil opportunity analysis (Cole Hill Associates, New Hampshire, 2004)

6. I.Y. Nuetral, Bark pinus pyrolysis bio-oil being using catalyst mo/clay grinning (Universitas Riau, Pekanbaru, 2015)

7. Setiadi, A. Pertiwi, Proc. of the 2nd National Congress and Symposium MKICS (2007)

8. P. Suarya, Jurnal Kimia FMIPA Universitas Udayana 2, 1 (2008)

9. Sunarno, S. Bahri, M.I. Fermi, R. Widiyanto, Prosiding SNTK TOPI 2012 (2012)

10. D. Mohan, C.U. Pittman, P.H. Steele, Energy \& Fuels 20, 3, (2006)

11. Dynamotive, Product information booklet (Dynamotive Bio-oil Information Booklet, Canada, 2006) 